\title{
Ideały społeczno-wychowawcze z perspektywy pedagogiki społecznej i władzy politycznej
}

\begin{abstract}
Social and educational ideals from the perspective of social pedagogy and political power
Abstract

The aim of this article is to show the contradiction between establishing social pedagogy as a scientific discipline and equipping the humans, especially youth, with a system of humanitarian values and at the same time, initiating practical activities aimed at improving the material conditions of life. The opposite of these humanistic aspirations of the scientific discipline is the destructive action of political power based on malicious intentions, subordinating to its power, often authoritarian, the life and behaviors of citizens. The government rejects his vocation to serve the common good and the country's development; and focuses on dominating all manifestations of collective and individual life. This striving for power reduces civil liberties and rights, divide society into hostile interest groups, and lead to abuse of violence and economic crisis. An additional nuisance for the society is the drastic neglect of social welfare, the disorganization of the infrastructure serving the public and the general disorganization of collective life. In this form, power can only be abolished.
\end{abstract}

\section{Keywords}

social ideals of humanistic, political power, mechanisms of exercising power, sources of power degeneration

Twórczyni polskiej pedagogiki społecznej - profesor Helena Radlińska - w odczycie wygłoszonym na posiedzeniu krakowskiego Koła Towarzystwa Nauczycieli Szkół Wyższych w dniu 25 kwietnia 1908 r., a więc 113 lat temu sformułowała następującą opinię: „Nie od dzisiaj ścierają się dwie zasady, na pozór sprzeczne - w gruncie rzeczy dopełniające się nawzajem. Jedna głosi: przetwórzmy duszę człowieka, druga - zmieńmy warunki tamujące rozwój człowieka, a dusze ludzkie (same) wyszlachetnieją"1.

${ }^{1}$ H. Radlińska, Z zagadnień pedagogiki społecznej, „Muzeum” 1908, t. II, Kraków, czasopismo Towarzystwa Nauczycieli Szkół Wyższych. 
Owszem, zasady te dopełniają się i w jedności tworzą najbardziej optymalne warunki pełnego rozwoju człowieka, czyli z jednej strony potrzebę posiadania określonych ideałów, motywacji, postawy wobec drugiego człowieka, a z drugiej strony - konieczność istnienia warunków materialnych, organizacyjnych, metodycznych, ..., aby ów ideał ukształtowania duszy człowieka został pomyślne osiągnięty. Te wyrażone przez H. Radlińską dwie zasady stanowią wprowadzenie do rozważań i treści, które „uczeń”, biograf i interpretator pedagogiki H. Radlińskiej prof. Wiesław Theiss - nazywa „traktatem założycielskim” polskiej pedagogiki społecznej.

\section{Dwa światy: humanizm nauki kontra „prawda” władzy}

Oczywiście rodzą się pytania bardzo zasadnicze, szczególnie w odniesieniu do pierwszego celu: o jaką duszę nam chodzi, jakie mają być jej właściwości, z czego wywiedzione, $w$ jakim systemie etycznym osadzone...? Mam wrażenie, że w epoce i warunkach, w jakich H. Radlińska wygłaszała swój odczyt, padłyby na te pytania trochę odmienne odpowiedzi niż dzisiaj. Odmienność warunkowałyby okoliczności narodowe, polityczne, cywilizacyjne... Aczkolwiek na pewno zmieściłyby się tam właściwości uniwersalne ważne i wówczas, i dzisiaj. Także w drugim członie postulowanej zasady musiałyby zostać uwzględnione pewne historyczne i kulturowe odmienności. Sama jednak zasada, iż wychowanie to $\mathrm{z}$ jednej strony system przeświadczeń aksjologicznych, osadzonych w systemie wartości ogólnoludzkiego humanizmu, a z drugiej strony to zespół materialnych warunków realizacji procesu wychowania, z cechami powszechności i równości w dostępie - nie uległby zmianie.

Ale oto to, co wydawało się być racjonalne i wymagające trudu myślicieli, wychowawców i organizatorów życia zbiorowego, staje się dzisiaj przedmiotem zaciekłych sporów, krańcowo odmiennych interpretacji, nieprzyzwoitych ataków instytucji politycznych, funkcjonariuszy politycznych, które - jak nigdy w przeszłości - uznały, że stanowią impotentną i wyłącznie uprawnioną instancję stanowienia prawdy, wyznaczania celów, rozstrzygania wszelkich niejasności. Zastanówmy się więc, czy prokuratorowi generalnemu RP chodzi o taką samą duszę młodego człowieka, o której się wypowiada w dzień po wyborach, 13 lipca 2020 r., kiedy oświadczył: „Stoi przed nami ogromne wyzwanie! Jeśli nie zajmiemy się edukacją, jeśli nie zajmiemy się sferą nauczania na uniwersytetach, jeśli nie zajmiemy się sferą mediów - to przegramy bitwę o polskie dusze"! Czyli dusza w tym wypadku nie jest owocem idealistycznej troski, opiekuńczych intencji wychowawcy, drogowskazem dla wychowanka - jak żyć godziwie dla drugiego człowieka, lecz jest zdobyczą, nad którą się będzie panować, którą się będzie sterować w pożądanym przez władzę kierunku, która będzie narzędziem walki! 
Oto różnica celów wychowania i wpływu na wychowanka między nauczycielem i wychowawcą a władzą polityczną. Dla uwiarygodnienia tej różnicy motywacji i celów posłużę się jeszcze jednym cytatem, szczególnego autorstwa: „Nie trzeba kupować narodu; wystarczy mieć tych inżynierów dusz, (...) i to zupełnie załatwia problem zniewolenia. (...) Prasa to broń najostrzejsza i najpotężniejsza naszej partii”'. Do kogo duchem swej wypowiedzi nawiązuje pan prokurator generalny: do idei Heleny Radlińskiej czy pragmatycznej dyrektywy genialnego językoznawcy?

Moim zamiarem jest ukazanie dwu różnych światów. Świata narodzonego z odwiecznych poszukiwań człowieka i tęsknoty za "rajskimi” warunkami życia i rozwoju rodzaju ludzkiego, którego głównymi walorami jest wolność: rozwoju, wyborów, osobistego dysponowania środkami tego rozwoju i osobistego określania celów, ku jakim człowiek chce zmierzać. Pragnienia te osadzone są w całym rozwoju ludzkiej cywilizacji: od mitycznych faktów raju, Adama i Ewy oraz wyjścia z raju do „pracy organicznej” na ziemi i tęczy jako symbolu przymierza człowieka z Bogiem, poprzez wielką filozofię Greków, Rzymian, średniowieczny Zachód Europy, które dokumentowały niezależność i wolność ustalania prawdy, bez kompromisów, nawet za cenę wypitej przez Sokratesa cykuty, czy straconego w więzieniu, w królestwie Ostrogotów, wielkiego teologa i filozofa AM. Boecjusza, który na przełomie V i VI w. wyraził wiekopomną prawdę: „Omnes malum ex potestas” („Wszelkie zło pochodzi od władzy”). Prawda ta przetrwała setki lat, do czasu, gdy papież Grzegorz VII w 1077 roku w Canossie odebrał hołd od króla niemieckiego Henryka IV, a tym samym odzyskał prawa inwestytury, czyli prawo nadawania koron władcom i kiedy to władza automatycznie stała się władzą z nadania boskiego. Znowu na kilkaset lat, zanim współczesne regulacje praw człowieka, m.in. Deklaracja niepodległości Stanów Zjednoczonych (1776 r.), Deklaracja praw człowieka i obywatela rewolucji francuskiej (1789 r.), Powszechna deklaracja praw człowieka ONZ (1948 r.) - nie sformułowały uniwersalnego „prawa ludu do obalania rządów, które nie przestrzegają przyrodzonych praw człowieka do życia i wolności”’.

Powołaniem człowieka wedle prawideł tego pierwszego świata zajmuje się myśl ludzka od zawsze. Jej cel określił bardzo udanie jeden z prekursorów pedagogiki społecznej - J.H. Pestalozzi, który tak go wyraził: „Starajmy się uczynić ten świat choć odrobinę lepszym, niż go zastaliśmy". Idea wyrażona w tej dyspozycji Pestalozziego oparta była na dramatycznych doświadczeniach osobistego udziału

2 J. Stalin, wypowiedź z okresu 1945-50 o roli elit w narzucaniu ustroju komunistycznego w Polsce. Źródło: „Oblicza PRL”, dodatek historyczny IPN do „Rzeczpospolitej” 2007, 20 listopada, nr 2, s. 13.

${ }^{3}$ Powszechna deklaracja praw człowieka ONZ, 1948. 
w wojnach napoleońskich i świadomości tragedii, jaką niesie wojna, szczególnie dzieciom. Resztę życia poświęcił praktyce tworzenia infrastruktury opiekuńczej dzieciom osieroconym, publikowaniu praktycznych przewodników „dobrego wychowania" dziecka. J.H. Pestalozzi, opierając się na ideałach oświatowych J.J. Rousseau, „tworzy szkołę nowoczesną, szkołę przenikniętą miłością dziecka, dążącą do harmonijnego rozwoju wszystkich wrodzonych sił i zdolności”"

Takie postawy intelektualne i podobną działalność znajdziemy w wielu kulturach i religiach Wschodu i Zachodu, u ludów cywilizacji prekolumbijskiej i afrykańskiej. Do wynaturzeń politycznych w tych dwu kulturach doszło dopiero w wyniku wiekowej zależności tych ludów i kultur od europejskich kolonizatorów. Za dzisiejsze polityczne patologie i tragedie ludów Ameryki Południowej oraz Afryki winna jest epoka kolonializmu. Zagubione zostały przez myśl społeczną niezwykle bogate treści „magicznego” humanizmu ludów pierwotnych, głębia praktyk taoizmu i konfucjonizmu oraz „racjonalnego” mistycyzmu hinduskiego - braminizmu, który „wieczną szczęśliwość” uzależnia od ludzkiego zachowania.

Świat pedagogiki społecznej ma postać uniwersalnych ideałów różnych kultur, religii i cywilizacji, które w jedność połączyła służbę człowiekowi i jego światu. Czyli ważna była owa mityczna lub realna dusza i równie ważne były warunki, w których taka dusza mogła zgodnie i godnie funkcjonować. Niestety przez większość historii człowieka taki model całościowy ludzkiego świata był utopią. Ale warto jednak zastanowić się, czy wartość utopii nie stanowi realnej siły kierującej potencjalnie siłami człowieka?

W tym drugim świecie najbardziej uniwersalną i sakralną wartością jest władza i panowanie! Powołaniem człowieka jest tej władzy służyć: intelektem, uczuciem i czynami. Instytucje władzy są równie stare jak tęsknoty człowieka do idyllicznej Arkadii, gdzie panuje pokój i beztroska szczęśliwość. Historia i metamorfozy władzy są nieograniczonym bogactwem wiedzy o ontologii życia społecznego przez kilka tysięcy lat istnienia zorganizowanego życia społecznego. Dziś po doświadczeniach XX wieku wydawać się może, że instytucja władzy, mając w dorobku dwa fenomeny systemu zła: faszyzm i bolszewizm oraz dwie najkrwawsze wojny światowe, będzie poszukiwać systemu politycznego, którego cechami będą: empatia, służba, wspieranie, opieka.

Otóż nic błędniejszego! Od czasów zakończenia II wojny światowej, w której zamordowano blisko sto milionów ludzi, na świecie nie było ani jednego dnia bez wojny. Zanim upadła „ojczyzna” systemu komunistycznego, narodziło się na świecie kilkanaście jej klonów, braci bliźniaków, w których okrucieństwa władzy (np. reżim Pol Pota w Kambodży) przewyższały okrucieństwem hitlerowski faszyzm. Poza kilkoma krajami o starych tradycjach demokratycznych (np. kraje

\footnotetext{
${ }^{4}$ H. Radlińska, Z zagadnień pedagogiki społecznej, op.cit.
} 
skandynawskie), na świecie narodziło się około 30 bezwzględnych despocji. Władza wspięła się na wyżyny propagandowej ekwilibrystyki, aby uzasadnić i usprawiedliwić swoje kryminalne, nieludzkie oblicza.

Władze całego świata albo są współwinne, albo obojętne wobec takich zbrodni ludzkości, jak na przykład sytuacja, gdy $218 \mathrm{mln}$ dzieci codziennie idzie nie do szkoły, lecz do pracy, w tym ponad $8 \mathrm{mln}$ do pracy niewolniczej. ${ }^{5}$. Do szkoły nie uczęszcza 400 mln dzieci, w tym połowa to dzieci w Afryce. 120 tys. dzieci bierze udział w wojnach jako żołnierze, większość w Ameryce Południowej.

Według raportu Banku Światowego ${ }^{6}$ pełna równość kobiet i mężczyzn jest gwarantowana tylko w sześciu państwach na 190 zbadanych krajów. A jest to zależne wyłącznie od woli władzy politycznej. Jedna trzecia ludności Brazylii, największego i najbogatszego kraju Ameryki Południowej, musi przeżyć dzień za jednego dolara. Polityka socjalna, pomoc społeczna - to pojęcia z innego świata.

I tak można by zapełniać podobnymi danymi całe tomy. I wszystkie owe zjawiska prawne, socjalne, oświatowe są pośrednim lub bezpośrednim owocem istnienia i działania władzy politycznej, tego drugiego świata tworzącego rzeczywistość realną, choć bardzo często opartą na kuriozalnych przeświadczeniach normatywnych, religijnych, aksjologicznych - tak jak choćby u nas, w Polsce A.D. 2021. „Najlepsze instytucje i największe bogactwa zaczynają działać wadliwie i są marnotrawione, gdy ich fundamentem przestaje być moralność, a ich przedstawiciele władzy kierują się już tylko egoizmem, pychą i bezczelnością"7 - powiedział Napoleon na Wyspie św. Heleny. Przecież ta prawda sprzed dwóch wieków jest ciągle aktualna nawet w Polsce, nie do końca jeszcze w zdeprawowanym państwie prawa.

Jakiż to paradoks i zmiana mentalności. Oto o tym samym Napoleonie spotykamy następujący sąd: „Wszyscy XX-wieczni autokraci, poczynając od Mussoliniego i Atatürka, po Stalina, Hitlera, Mao Tse-tunga naśladowali Bonapartego, prekursora i wzorca współczesnych tyranów. Sukarno w Indonezji, Ho Chi Minh, Pol Pot, Nasser, Saddam, Perón, Castro, Kadafi, Bokassa, Idi Amin. Wszyscy dopuszczali się najstraszliwszych bestialstw: od ludobójstwa do ludożerstwa"s.

Degradacja moralna władzy nie jest jakimś procesem wedle reguły continuum. W starożytności mieliśmy Juliusza Cezara, uznawanego za jednego z największych zbrodniarzy ludzkości (na ówczesne kryteria: wódz-bohater!) i Marka Aureliusza - cesarza - stoika, głoszącego etykę wewnętrznej harmonii i nakazu miłości. W trzecim wieku przed naszą erą żył cesarz indyjski Aśoka, twórca imperium, słynny z tolerancji, wyznawca etyki buddyjskiej. Rozwijał przyjazne stosunki

\footnotetext{
${ }^{5}$ Raport Międzynarodowej Organizacji Pracy, 2006.

${ }^{6}$ Dane z 2004 r.

7 P. Johnson, Bohaterowie, Warszawa 2009, s. 312.

${ }^{8}$ Ibidem.
} 
ze światem, budował szpitale dla ludzi, zwierząt i roślin. Na skałach i kolumnach kamiennych wyrył inskrypcje głoszące humanitarne zasady buddyzmu... Ale zanim wstąpił w młodości na tron, kazał wymordować wszystkich braci i innych krewnych, możliwych kontrkandydatów do korony. Gasił krwawo bunty w prowincjach. Ten sam człowiek władzy!

W średniowieczu na kilkunastu władców Francji był jeden „sprawiedliwy”: Ludwik IX - święty, podobno zasłużenie kanonizowany. A nieopodal, trochę później, w Rosji żył Iwan IV Groźny, rzekomo największy okrutnik wśród władców swoich czasów.

O ile jednak wśród przedstawicieli władzy, od starożytności do współczesności, udaje się z wielkim trudem odnaleźć kilka postaci moralnie nieskazitelnych, to trudno znaleźć taką zbrodnię, której by nie popełnili dzierżyciele władzy od Władywostoku po Lizbonę i od czasów Mojżesza do prezydenta Trumpa. A należy dodać, że większość z nich żyła w klimacie kultu, nawet sakralnego i z różnym nasileniem odbierali boskie uwielbienie. Podobnie jak dzisiaj! Jakże głęboki kult otacza Łukaszenkę, Putina, Orbana, nawet naszego Kaczyńskiego, który ochoczo przyznaje sakralne kwalifikacje swemu pupilowi prezesowi ORLENU, twierdząc, że tylko Bóg może wyposażyć człowieka w pewne właściwości. Byłoby to może śmieszne, gdyby nie pociągało za sobą tragicznych konsekwencji gospodarczych i politycznych. Jest nieprzeniknioną tajemnicą, dlaczego jedne kraje mają zakodowaną niezawodną kryminalizację władzy (np. Rosja), inne silne skłonności do patologizacji władzy (np. Polska), a inne jeszcze nie zdradzają żadnych skłonności do rządów totalitarnych (np. Dania).

Od zbrodni - jako modus operandi - nie stroni także władza mająca aspiracje władztwa duchowego. Nie warto wracać do mroków średniowiecza i tzw. świętej inkwizycji ani licznych sekt ówczesnych czasów, np. biczowników. Pod koniec XX wieku, w listopadzie 1978 roku w miejscowości Jonestown w Gujanie, 909 osób w tym 300 dzieci - „dobrowolnie” popełniło samobójstwo za namową i na polecenie swego guru (ale pod kontrolą i presją jego „pomocników”). Przywódca religijny, uważający się za boga Jim Jones, zdolny demagog, założył sektę „Świątynia Ludu". Aby uciec od kontroli władz Stanów Zjednoczonych, przeniósł swoich wyznawców do Gujany. Tam, wyłudziwszy od nich wszelki majątek, wykorzystując ich niewolniczą pracę, doprowadził do całkowitego zniewolenia swych wyznawców, posługując się kłamstwem, bezczelną psychologiczną manipulacją, prymitywną propagandą wymusił zbiorowe samobójstwo, przy sformalizowanej bezwolności władz i Gujany i Stanów Zjednoczonych, które się wzajemnie szachowały.

$\mathrm{W}$ tym tragicznym zdarzeniu trzeba też dostrzec pewne formy poszukiwania przez człowieka idealnego ładu moralnego, jakiejś Arkadii wolności i spełnienia, wykorzystane cynicznie przez bezwzględnych manipulatorów. Czy można sobie wyobrazić, że na miejscu Jima Jonesa jest św. Franciszek z Asyżu!? Może nawet 
członkowie „Świątyni Ludu” wierzyli, że jest to nowy mesjasz. I wówczas powstałaby wspólnota tworząca jakieś dobro publiczne...

Kiedy obserwujemy działania władzy politycznej, nawet nie okrutnych despocji dawnej Birmy, dzisiaj Mjanmy, ale także społeczeństwa Białorusi, Węgier, Rosji, ...., a jakże, także Polski, łatwo dostrzeżemy potęgę manipulacji, olbrzymie działanie propagandy, w którą wierzą miliony... Jak i czym możemy wytłumaczyć, że bezwzględny i okrutny zbrodniarz, który miał na sumieniu dziesiątki milionów niewinnych ofiar - Józef Stalin - został niemal „spontanicznie” nominowany na świętego cerkwi prawosławnej? Do dzisiaj istnieje kult Stalina. Wielu tych wielkich zbrodniarzy było uważanych za mężów opatrznościowych, mimo że ich ręce ociekały krwią.

To tylko ziarenka piasku z tej wielkiej piaszczystej pustyni wypełnionej niepoliczalnymi tonami ziarenek władzy politycznej, która zapełnia nasz świat realny, społeczeństwa różnych czasów, kultur, religii, które żyły i żyją pod władzą psychopatycznych wodzów, którzy na tysiące sposobów przekonują, że posiedli „mandat niebiański” (określenie Konfucjusza) i pod tysiącami nazw sprawują rząd dusz, posługując się trzema głównymi instrumentami władzy: przemocą (wynajętą), bogactwem (kradzionym) i wiedzą (instrumentalną).

Z powyższych uwag wynikają też pewne wnioski wskazujące na genezę władzy. Pierwszy wskazuje na posiadanie władzy z nadania boskiego. Była to najpowszechniejsza argumentacja, trwająca wręcz całe tysiąclecia. Interpretacją taką posługiwały się wszelkie religie. Niektóre religie starożytne uznawały władcę za swoiste wcielenia boga (starożytny Egipt, Rzym, niektóre religie animistyczne). Ponadto wiara w boskie pochodzenie władzy nadawała tej władzy cechy sakralne, czyniąc ją nietykalną i podnosząc na poziom niedostępny dla poddanych. Reliktami tej interpretacji pochodzenia władzy są dzisiaj tradycyjne napisy na przykład na monetach krajów posiadających urząd monarchy. Na monetach brytyjskich i krajów Wspólnoty obok portretu Królowej jest skrót informacyjny: D. G. Reg. Elizabeth II (Deo Gratias Regina Elizabeth II, Dzięki Bogu Królowa Elżbieta II). Dziś monarchie w olbrzymiej większości odgrywają rolę symboli historycznych, emocjonalnych, prawnych - podnosząc prestiż cywilnych rządów.

Rządy cywilne, świeckie, pod naciskiem społecznym i groźbą konfrontacji z buntem obywatelskim stwarzają całe prawne i instytucjonalne oprzyrządowanie imitujące właściwości instytucji demokratycznej, tzw. demokracji proceduralnej, nawet w całkowicie zdeprawowanych despocjach (np. Węgry, Turcja, Polska) albo całkowicie jawnie stosują kryminalny terror (np. Białoruś, Birma, Rosja). W ocenie międzynarodowych rankingów praworządności, do grupy krajów respektujących w pełni prawa obywatelskie zaliczanych jest kilkanaście krajów. Ogromna większość państw łamie regulacje prawne narzucane przez międzynarodowe konwencje i traktaty albo jawnie, albo pod pokrętnymi argumentami. 


\section{Polska krajem prawa czy bezprawia?}

Największą trudność sprawia nam określenie ustroju naszego kraju. Nie jest to ani faszystowska dyktatura, ani też komunistyczna despocja. Choć z każdego z wymienionych systemów znajdziemy w naszym ustroju liczne cechy. Posiłkując się esejem Umberto Eco pt. Ur-faszyzm, opublikowanym w 1995 roku w „New York Review of Books" oraz dziełem Timothy Snydera pt. O tyranii. Dwadzieścia lekcji $z d w u d z i e s t e g o$ wieku $u^{9}$, spróbujmy spojrzeć na nasz ustrój przez pryzmat rozważań tych dwu znakomitych współczesnych intelektualistów.

Ustrój polityczny Polski po 2015 roku, za sprawą świadomych decyzji rządu PiS, zapożyczył z faszyzmu zachowania dyskryminacyjne i prześladowcze wobec obywateli odmiennych orientacji różnej natury, uprzedzenia rasowe, upodobanie do jedności. Ponadto $\mathrm{z}$ właściwości faszyzmu rząd polski przejął nerwicowe traktowanie krytyki jako zdrady kraju i narodu. Rząd nasz wzorem faszystów skupia swoją uwagę na sprawach seksu. Potępia wszelką odmienność. Jawnie pokazuje pogardę dla kobiet. Kontroli chce poddać ich autonomię biologiczną, odebrać prawa do decydowania o swojej płciowości i płodności. Działania i czyny funkcjonariuszy systemu nie podlegają osądowi publicznemu. Jeśli są atakowane, to jest to traktowane jako zorganizowany atak na prawdę i praworządność.

Ta ostatnia cecha jest także typowa dla mentalności komunistycznej. Z komunistycznego systemu Polska dzisiejsza przywłaszczyła przede wszystkim system jednopartyjnej władzy. Z komunistami łączy nas styl rządów PiS-u i sakralny stosunek do wodza partii. Z komunistycznej praktyki nasz rząd wziął upodobanie do tworzenia instytucji i organów o niejasnych celach i kompetencjach, ale o wyraźnej, nobilitującej przynależności do narodu, ojczyzny, historii. Każda taka instytucja jest albo narodowa, albo polska, albo chrześcijańska (np. „Reduta Dobrego Imienia”, „Ordo Iuris”, Polska Fundacja Narodowa, „Duma i Nowoczesnośc”, Instytut Pamięci Narodowej). Z komunistyczną przeszłością łączy nasz rząd upodobanie do organizacji paramilitarnych, oczekiwanie bezwarunkowego posłuszeństwa oraz sprawny system opresyjny, do czego nakłonił bez większego trudu dowódców polskiej policji.

Wszystkie te cechy były manifestowane przez polski rząd w ostatnich latach. Poza brutalnością policji wobec kobiet i młodzieży, która została wyraźnie zalecona przez kierownictwo policji, a to zalecenie wiązało się z sutymi dotacjami rządu, to polskie państwo nie prezentuje okrucieństwa na wzór faszyzmu ani rosyjskiego komunizmu. Zastępuje go wyćwiczoną na mistrzowskim poziomie kłamliwą propagandą, zmasowanym naciskiem kłamstw i przeinaczeń na społeczną świadomość obywateli.

\footnotetext{
9 T. Snyder, O tyranii. Dwadzieścia lekcji z dwudziestego wieku, Kraków 2017.
} 
Natomiast polskim władzom, wbrew deklaracjom, są całkowicie obce konsultacje społeczne, partnerskie kontakty z obywatelami. Władze są całkowicie zamknięte na korzystanie w swojej polityce z jakichkolwiek elementów badań i diagnoz naukowych ukazujących społeczne aspekty życia i pracy obywateli. Przypadek polskiej władzy rządzącej krajem od 2015 roku jest klasycznym przykładem istnienia w całkowitej izolacji wobec siebie świata nauki, owoców jej badań, diagnoz i projektów reformatorskich ze światem władzy politycznej, całkowicie obojętnej na potrzeby społeczne ludności, na perspektywy rozwojowe wykraczające poza termin najbliższych wyborów. Sądzę, że Polska jest w tym zakresie wzorcem modelowym. Można powiedzieć więcej: politycy powołani np. do kierowania najważniejszym obszarem strategii rozwoju i przyszłości państwa - edukacją młodego pokolenia, legitymują się mentalnością średniowiecznych mnichów, całkowicie zamkniętych na treści wykraczające poza ich skostniałe przekonania. Na domiar są tak głęboko przekonani o posiadaniu jedynie słusznej prawdy, że nie dopuszczają nawet myśli o debacie, wymianie poglądów, respektowaniu innych racji prócz własnych.

Cała formacja polityków PiS dokonała antropomorfizacji ideologii LGBT, wtłaczając w ten symbol konkretne grupy społeczne. Jest to oczywiste nadużycie semantyczne i logiczne, ale czegóż się nie robi, aby umocnić swoją władzę. W tym wypadku PiS-owi potrzebny był pretekst: divide ut regnes (siej waśń, abyś mógł rządzić). „Mordy zdradzieckie” Kaczyńskiego już nie są nośne... „Gdzie staliśmy my, a gdzie oni” - sam prezes już zapomniał. Więc sięgnijmy do potencjalnych nowych strachów, zasiejmy nienawiść, łatwiej wówczas rządzić. Sięgnięto do zasady używanej jeszcze przez senat rzymski, potem wypowiadanej przez Filipa, króla Macedonii, wreszcie przez Ludwika I, króla Francji. Ale zasadę taką do genialnej skuteczności doprowadzili wszelkiej maści satrapowie historyczni i współcześni. Wystawiono „ciemnemu ludowi” (cyt. za J. Kurskim) nowego wroga, zagrażającego chrześcijańskiej tożsamości narodu polskiego - ideologię LGBT. Ideologia LGBT była potrzebna jako instrument podziału społeczeństwa na wrogie orientacje. Była potrzebna jako podpałka dla rozniecenia pożaru nienawiści i waśni grupowych. Była to premedytacja nacechowana przemyślaną strategią ukrycia spraw dla władzy kłopotliwych i skierowania uwagi i emocji na sprawy zupełnie nieważne dla normalnego funkcjonowania aparatu państwa. Dlaczego w tę politykę nienawiści plemiennej dał się wmanewrować Kościół katolicki, więcej - dał swoje religijne placet dla tej nienawiści wypowiedzią swego prominentnego funkcjonariusza - abpa Krakowa Jędraszewskiego - nie sposób zrozumieć!

Oto prezydent Duda, wraz z drugim mężem stanu Czarnkiem, wołają na wiecach w 2020 r.: „Skończmy słuchać tych idiotyzmów o jakichś prawach człowieka czy jakiejś równości! Ci ludzie (określani jako LGBT) nie są równi ludziom normalnym!”. I dalej sam Czarnek przedstawia historiozoficzne korzenie LGBT: „Nie 
ma wątpliwości, że cała ta ideologia LGBT wyrastająca z neomarksizmu pochodzi z tego samego korzenia, co niemiecki, narodowy, hitlerowski socjalizm”. „Ciemny lud" (J. Kurski) kupił światłe nauki prezydenta i ministra od nauki i w blisko stu gminach i miejscowościach ogłosił strefy wolne od LGBT. Przerażona Europa przysiadła z wrażenia. Pani przewodnicząca Parlamentu Ursula von der Leyen wyraziła nieśmiałą uwagę, że „bycie sobą - to tożsamość człowieka, a nie ideologia”. 50 ambasadorów $\mathrm{z}$ całego świata stanęło w obronie osób o odmiennej orientacji seksualnej, w tym największe demokracje świata....

Ale to nie ostudziło determinacji rycerzy narodowej walki o prawdę i kierunek zdrowego rozwoju edukacji. Oto przedstawiciel ministra nauki ds. programów nauczania i podręczników dr Artur Górecki, aktywista oryginalnej organizacji „Ordo Iuris", wygłasza credo na prezentacji zespołu kierowniczego Ministerstwa Nauk i tak rysuje swoje zadanie: „Moją intencją będzie pilnowanie, aby treści podręczników i wiedza przekazywana młodzieży nie stały się przeszkodą na drodze do jej zbawienia".

Oto co potrafi zrobić z krajem o tysiącletniej historii kilku osobników dotkniętych zamrożeniem zdrowego rozsądku. Polska w prestiżowych rankingach spadła na końcowe rejestry tabel. W najnowszym rankingu „Democracy Report” (2021) zajęliśmy pierwsze miejsce wśród państw najszybciej staczających się w autokrację. A przecież, jak to ogłosił premier polskiego rządu: „Polska to wyspa wolności i tolerancji”. Ta rozbieżność ocen naszej polskiej rzeczywistości między opiniami międzynarodowych instytucji badawczych a rządową propagandą naszej polityki jest zatrważająca. Tym bardziej, że zaskarżony czyn odnowienia średniowiecznego zwyczaju wieszania zastępczego (portretów „złoczyńców”) został uznany przez prokuratora za usprawiedliwioną formę wyrażania opinii.

Czy między opisaną wyżej rządową, polityczną ideologią wychowania, kształtowania stosunków międzyludzkich a pryncypiami ideowymi wychowania społecznego naszej dyscypliny może istnieć jakakolwiek łączność? Helena Radlińska w cytowanym wykładzie dla nauczycieli szkół wyższych m.in. tak określa cele wychowania przyszłych szkół kształcących młodzież: „Szkoły (ukształtowane) przez idee Komisji Edukacji Narodowej, stworzone przez działaczy, którzy usiłowali pchnąć Polskę na nowe tory - miały wychowywać pokolenia wolne od przesądów, świadome błędów społecznego ustroju, przejęte potrzebą reform - nie wahały się więc wdrażać młodzieży do krytyki urządzeń publicznych. Izba edukacyjna z naciskiem zaznacza, że chce wychowywać »objaśnionych« obywateli i opierać swój program na rozpoznanej potrzebie kraju (...) Szkoła ta odpowiada potrzebom wolnego życia i ideałowi wolnego, pełnego człowieka"10.

${ }^{10}$ H. Radlińska, Z zagadnień pedagogiki społecznej, op.cit. 
Tym ideałom wychowania i wzorom osobowym wychowanków pedagogika społeczna jest wierna od swego powstania, poprzez trudne lata pierwszego okresu sterowania nauką i podporządkowania jej partyjnym i ideologicznym dyrektywom w czasach komunistycznych, do dzisiaj, kiedy „upartyjnione” kierownictwo edukacji chce implementować swoje chore wizje ładu edukacyjnego.

\section{Państwo autorytarne wyklucza partnerstwo, opiekę i społeczeństwo obywatelskie}

Spójrzmy teraz na wybrane obszary i elementy edukacji oraz rzeczywistości społecznej, w których całkowicie rozmijają się pryncypia humanistycznego kształtowania człowieka i jego środowiska życia, z pryncypiami politycznymi i regułami pragmatyki społecznej rządzącej partii.

Pierwszym głównym rysem polskiego państwa jest nietolerancja. I jest to jeden z najstarszych grzechów społecznych polskiego państwa i społeczeństwa, mimo dumnej opinii premiera o Polsce jako wyspie wolności i tolerancji. Tolerancją na tle Europy Polska mogła się pochwalić w wiekach XII-XIV. Był to czas, gdy zaraza nietolerancji dotknęła cały niemal świat chrześcijańskiego Zachodu. To wówczas pojawia się nietolerancja religijna i w wyniku specyficznych zależności finansowych władców chrześcijańskich - antysemityzm.

To czasy walki o „odzyskanie Ziemi Świętej” (7 wypraw krzyżowych, w tym jedna „dziecięca” w XI-XIII wieku), narodziny inkwizycji (1184 r.), wypędzenie Żydów z całej niemal Europy Zachodniej, ponieważ byli głównymi wierzycielami długów królewskich i papieskich, których ani papież, ani król Hiszpanii, ani Anglii nie zamierzali spłacać, a sposobem na pozbycie się długów było pozbycie się wierzycieli pod pretekstem ich winy za śmierć Chrystusa. To czasy napływu Żydów na tereny wschodniego chrześcijaństwa, w tym na ziemie polskie i krajów sąsiednich, gdzie znaleźli przyjazny klimat do osiedlania się i życia. Sielanka tolerancji dekretowana edyktami królewskimi Henryka Pobożnego i Kazimierza Wielkiego przetrwała wobec Żydów dość długo. Ale już za dynastii Jagiellonów Polska przeradza się w państwo stanowe, o postępującym procesie różnicowania klasowego, narastających aspiracjach władczych szlachty i popadającej w coraz głębsze poddaństwo chłopstwa oraz ograniczana coraz mocniej „suwerenność” mieszczaństwa. Kolejne regulacje prawne: Neminem captivabimus (1425), Nihil novi (1505), Liberum veto (1652) czyniły z Polski kraj stratyfikacji, gdzie „naród szlachecki” (innego nie było), stanowiący ok. $10 \%$ populacji ludności, był wszechwładnym suwerenem, wyposażonym we wszechmoc prawną i realną, pozostałe blisko 90\% populacji, głównie chłopstwo, zostało pozbawione wszelkich praw i sprowadzone, podobnie jak rzymski niewolnik, do „mówiącego narzędzia pracy”, które można sprzedać, 
nie wyrazić zgody na małżeństwo, zabić za niewielką grzywnę. Owe prawne regulacje, przy sprzyjającym klimacie jezuickiego (czyli wówczas prymitywnego) wychowania szlachty, czyniły z Polski kraj narastającej, patologicznej nierówności i manifestowanej pogardy dla źle urodzonych.

Wtedy także narodziła się idea i świadomość społecznych nierówności, która była i jest naturalną glebą dla nietolerancji. Same narodziny nierówności stały się archetypem polskich wyobrażeń o strukturze ludzkich zbiorowości. Utrwalone zostały te schematy na kilka wieków jako naturalny model struktury ludzkich zbiorowości. Te schematy postrzegania i zachowań obserwujemy w literaturze pierwszej połowy XX wieku. Z takimi zachowaniami spotykamy się jeszcze dzisiaj. Wiele patologicznych zachowań politycznych można wytłumaczyć mitycznymi odniesieniami do tych „zdobyczy” demokracji „narodu szlacheckiego”.

Tymi m.in. historycznymi uwarunkowaniami można tłumaczyć arogancję rządzących, pogardę dla „ciemnego ludu”, skłonności do autorytaryzmu władzy. Duch „wyższości” świadomie lub podświadomie kieruje zachowaniami dzisiejszej klasy politycznej - nowej szlachty, która nagina prawo wedle zasady z $1425 \mathrm{r}$. Neminem captivabimus (liczne przypadki wyczynów prokuratury krajowej uwalniającej swych „lepiej urodzonych") lub decydującej wedle zasady Nihil novi z 1505, nic nowego nie może być postanowione bez zgody naszej, partyjnej lub ew. Prezesa!

$\mathrm{W}$ nawiązaniu do wymienionych wielkich dokumentów narodowych i międzynarodowych warto uświadomić sobie ich złudną siłę. Deklaracja niepodległości Stanów Zjednoczonych do dzisiaj nie zrównała całkowicie wszystkich obywateli tego kraju. A jak ocenić siłę ONZ-owskiego dokumentu z 1948 roku o prawach człowieka, jeśli badania dowodzą, że np. równość obywatelska między mężczyznami i kobietami respektowana jest tylko w sześciu krajach świata na 190 badanych? Ten sam skutek możemy obserwować wobec zgłoszonej przez Polskę w 1978 roku Deklaracji o wychowaniu społeczeństw w duchu pokoju - jeśli wiemy, że od zakończenia II wojny światowej ziemia nie zaznała ani jednego dnia pokoju?!

To jest obezwładniająca świadomość rozbieżności między szlachetnymi pobudkami i nawet realnymi przedsięwzięciami a rzeczywistością. I to rodzi dodatkową wątpliwość. Jak odróżnić szlachetne przedsięwzięcia, które w dobrej wierze składali ich autorzy, od perfidnej propagandy, którą uprawiają cyniczni politycy z zamiarem oczywistego stworzenia pustosłowia, za którym nigdy nie pójdzie nawet pozorny gest dobrej woli? Oto w latach 20 . XX wieku Lenin stworzył Deklarację praw ludu pracującego i wyzyskiwanego, którą proklamowała Rosja bolszewicka. Znajomość historii pozwala nam odnieść się do takiej deklaracji jako do historycznego oszustwa, propagandowego chwytu, którego celem było stworzenie wyłącznie zasłony dymnej dla jednego z najokrutniejszych systemów opresji człowieka. Bliźniaczą Deklarację praw narodów Rosji napisał J. Stalin, gwarantującą narodom Rosji wszelkie prawa wolności, równości i samostanowienia. I dziś wie- 
my, że to był początek prawie wiekowego, bezwzględnego i uniwersalnego terroru, nieznanego w historii. Nigdy nie poznamy motywacji tworzenia takich dokumentów. Znaleźlibyśmy ich bliźniacze kopie w Chińskiej Republice Ludowej, na Kubie i w wielu jeszcze reżimach. Jakie były intencje autorów? Czy to specjalny nurt myślenia i działania, wyrastający z przemyślanej perfidii twórcy? Czy może autentyczna dobra wola, zablokowana przez niepomyślny bieg zdarzeń, czy wreszcie rodzaj politycznej socjotechniki, której celem była premedytacja i osiągnięcie określonych efektów? Jak wiadomo całe szeregi intelektualistów Zachodu, szczególnie Francuzów, korzystało z zaproszeń władz sowieckich, zwiedzali „potiomkinowskie" placówki i głosili po świecie chwałę radzieckiego świata powszechnej szczęśliwości. To był instytucjonalny początek powszechnej, kłamliwej propagandy, będącej dzisiaj w powszechnym stosowaniu.

Taką właśnie sytuację mamy w naszym kraju określonym przez premiera Morawieckiego „wyspą wolności i tolerancji”. Tolerancja jest ostatnią właściwością zarówno władzy publicznej, jak i naszego społeczeństwa. Tworzone są specjalne kategorie ludzi, idei, poglądów, zachowań, które celowo są wystawiane na nietolerancyjne traktowanie. Wbrew biblijnej tradycji, wedle której tęcza po potopie stała się symbolem przymierza Boga z Człowiekiem, tęcza została zadekretowana przez jednego z najważniejszych hierarchów katolickich symbolem homoseksualnej orientacji i sprowadzona do roli symbolu hańby, za używanie którego władze stawiają przed sądem. Jaki rodzaj aberracji myślowej musiał towarzyszyć przedstawicielom władzy, aby piękny symbol boskiej miłości do człowieka sprowadzić do roli haniebnego znaku, nazwanego tęczową zarazą? Sądzę, że to zjawisko dobrze ilustruje ten nurt myśli władzy politycznej, której celem jest panowanie nad „ludem”, a nie służenie „ludowi”. Bo jakże władza mogłaby służyć „gorszemu sortowi”, „mordom zdradzieckim”, „krytykom władzy, którzy działają na szkodę kraju, narodu, dobra publicznego" (cytaty z wystąpień publicznych polityków sprawujących władzę)?

Nietolerancja jest więc immanentną cechą polskiej umysłowości. I była rozniecana niemal zawsze przez władze, także przez Kościół katolicki. Zdaniem N. Daviesa - Polak, obok Brytyjczyków, ma najbardziej rozdęte ego. Nie toleruje cudzoziemców wedle zróżnicowanych kryteriów, np. wyznania, koloru skóry, nawet sposobu ubierania się. Szczególną pozycję wśród obcych zajmują Żydzi. Jak $\mathrm{w}$ wielu innych kwestiach spotykamy się tu ze swoistym paradoksem. Najświętsza Maria Panna jest przedmiotem najwyższego sakralnego uwielbienia. Jej syn Jezus Chrystus powszechnie i potocznie jest uznawany za głównego Boga. Oboje są Królową i Królem Polski. I tak jest od wieków. I od wieków nie zmienił się tragiczny stosunek do Żydów. Archiwa Akt Starych i Archiwa Akt Nowych zawierają najbogatszą dokumentację aktów agresji, nienawiści, gwałtów, zamachów kryminalnych na ludność żydowską lub na osoby za takie uważane. 
Nie historia, lecz ostanie dni rozpoczętego, nowego roku przyniosły informacje, że „krzewiciele” tolerancji z „Ordo Iuris” złożyli projekt ustawy ustanawiającej "klauzulę sumienia” dla hotelarzy i właścicieli wynajmu, zezwalającej na odmowę przyjęcia gości, wobec których istnieje podejrzenie, że reprezentują „niewłaściwe” wyznanie, kolor skóry, orientację seksualną. I dzieje się to w trzeciej dekadzie XXI wieku, w środku Europy, w „kraju będącym wyspą wolności i tolerancji”. Jak odczytać ten gest? Przywiązaniem do średniowiecza, a może tylko manifestacją prymitywnej głupoty? Ale takie gesty tworzą klimat kraju, społeczne impulsy zachowań. Mamy wszak klauzule sumienia dla lekarzy, farmaceutów. Można by powiedzieć: wstyd - wszak to ludzie wykształceni. Ale na ich korzyść przemawia okoliczność, że klauzulę podpisało nieco ponad 4 tys. osób. Jest to wobec ogólnej liczby uprawnionych niewielki ułamek. Ale i taki ułamek jest wstydem tego zawodu!

Wskutek propagandowych nacisków władz centralnych blisko 100 samorządowych jednostek ogłosiło swoje terytoria „strefami wolnymi od LGBT”. Oczywista jest inspiracja władz centralnych, bo nikt w gminie ani innej małej miejscowości nie wie, czym jest ten dziwoląg onomastyczny i dlaczego należy chronić to małe terytorium od jego wpływów. Pomijam bełkot logiczny i moralny towarzyszący próbom zdefiniowania, czym jest owo tajemnicze LGBT. Ale skutki są następujące: pojawił się ważny sygnał dla zachowań ksenofobicznych, nietolerancyjnych. Z niejasnych „dla rządzących” powodów partnerzy z zachodniej Europy zaczęli zrywać współpracę, odmawiać kontaktów, cofać dotacje... Wszystko w klimacie oburzenia na „zaściankowość" polskich partnerów. Wstyd, szkody prestiżowe i materialne, poczucie wykluczenia z cywilizowanego świata! To chciała osiągnąć władza centralna czy inne „Reduty Dobrego Imienia”? Niektóre samorządy ze wstydem wycofały się ze swych decyzji. Ale większość utwierdzona państwową, żenującą propagandą i specjalnymi dotacjami utrzymała swoje decyzje. I tak Polska stała się pariasem kulturowym Europy i zainspirowała Parlament Europejski do ogłoszenia Unii Europejskiej strefą wolności dla LGBTIQ. I mimo to państwowa machina propagandowa idzie w zaparte i broni swoich racji, głosząc, ustami prezydenta RP, że nie będzie nikt w obcych językach uczył nas prawdziwej kultury. Jakie ślady zostaną $\mathrm{w}$ świadomości Polaków po tym incydencie? O ile zapełni się obszar nietolerancyjnej wrogości wobec idących z Europy impulsów kulturowych? Czy ta dramatyczna afera z tęczą, ,wyznawcami”(?) LGBT, rozpętanie na tym tle klimatu nienawiści nie jest manifestacją wrogości rządzących wobec pryncypiów ewangelicznych chrześcijaństwa? Odstępstwa od najważniejszego przykazania chrześcijaństwa (Ew. Mateusza 22, 37-40; Ew. Marka 12, 29-31; Ew. Łukasza 10, 27)?

Jakby mało było wstydu międzynarodowego, w początkach kwietnia $2021 \mathrm{r}$. wpłynął do sejmu wniosek tejże kuriozalnej organizacji „Ordo Iuris” projektujący wypowiedzenie konwencji stambulskiej zakazującej - mówiąc w skrócie - stosowania przemocy wewnątrzrodzinnej szczególnie wobec kobiet i dzieci. Tu należy 
zauważyć, że konwencji tej nie podpisały dwa kraje - „wzorce demokracji i praw człowieka" - mianowicie Rosja i Azerbejdżan. Na początku roku 2021 konwencję wypowiedział satrapa Turcji Erdogan, gwałcąc przy okazji własną konstytucję. I oto do tego towarzystwa „wysp tolerancji i wolności” dołączyć ma Polska, której sejm skierował ową propozycję „Ordo Iuris” do dalszego procedowania! „O tempora! O mores!” - chciałoby się wołać za Cyceronem!

Dla ludzi związanych emocjonalnie z Polską i z polskością ta polityka rządu jest jakimś kuriozum bezsensu, można by rzec, że to wrogie wobec Polski działanie. O polskiej nietolerancji istnieją analizy i opracowania zdolne wypełnić obszerną bibliotekę. Dla pedagogiki społecznej budowanie klimatu nienawiści, wykluczenia, naznaczenia jest aktem tak sprzecznym $\mathrm{z}$ wyrażonym przez H. Radlińską na początku tego opracowania kształtowaniem duszy człowieka, że w gruncie rzeczy jest to blokada rozwoju tej humanistycznej dyscypliny nauki. Obciążona skutkami takich uczuć i zachowań nie będzie w stanie budować więzi międzyludzkich, fundamentu zdrowego społeczeństwa. Usuwanie i neutralizowanie tej prawdziwej „zarazy” stosunków międzyludzkich - nietolerancji - z ducha i umysłowości Polaków zajmie instytucjonalnemu wychowaniu kilka pokoleń. A jeśli los ukarze Polskę i Polaków podobną władzą do tej, która ma osobliwą nazwę: prawa i sprawiedliwości - to trudno będzie znaleźć dla Polski i Polaków miejsce w rodzinie cywilizowanych narodów.

Drugim obszarem, na którym dochodzi do dramatycznych dysfunkcjonalności władzy politycznej w działaniu, ale w pierwszym rzędzie do odrzucenia przez polską władzę polityczną fundamentalnego systemu aksjologicznych przeświadczeń, jest jej stosunek do ludzi dotkniętych różnorodnymi postaciami niesprawności: fizycznych, mentalnych, dramatem upadku materialnego, bezdomnością, ubóstwem, starością, wykluczeniem, przynależnością do obcej kultury, rasy, religii - jednym słowem ludzi noszących widoczne cechy odmienności. Polska ma system opieki socjalnej o dużych tradycjach i wielu humanitarnych zasługach. Bogatą i różnorodną działalność charytatywną od pierwszych wieków chrześcijaństwa prowadziły liczne zgromadzenia zakonne i instytucje kościelne. Do historii weszły nazwy: „bracia szpitalni”, bożogrobowcy, joannici, klaryski, beginki, szarytki, felicjanki... Mamy w historii piękne postacie, nawet świętych: brat Albert (Adam Chmielowski 1845-1916), bł. Honorat Koźmiński (1829-1916), Janusz Korczak (1878-1942). Mamy piękne postacie współczesne: Jacek Kuroń, siostra Małgorzata Chmielewska, Anna Dymna, Janina Ochojska, Jerzy Owsiak. Nie bez znaczenia dla idei pedagogiki społecznej istniały w tradycjach ludowych formy lokalnego wspierania potrzebujących, noszących cechy formalnego procederu pomocy, obowiązujący całą społeczność lokalną, np. codziennym posiłkiem głównym serwowanym w ustalonej kolejności. Zwyczaj ten przetrwał w Małopolsce do lat 60. XX wieku. 
W świetle tych wspaniałych, wielowiekowych tradycji dobroczynności, to nasz rządowy system zabezpieczenia socjalnego jest dramatycznie niewydolny. Z przyczyn demograficznych i wielu innych rośnie liczba ludzi potrzebujących wsparcia (starość, kalectwo, bezdomność...). Tymczasem środki wsparcia są niedostateczne, ich dystrybucja zawodna, kadry nieliczne i często bezradne...

Innym obszarem ograniczonej odpowiedzialności socjalnej państwa są dzieci z niepełnosprawnościami. W tej kwestii oburza szczególnie skala hipokryzji władz politycznych, które prowadzą zaciekłą walkę z polityką aborcji i ogólnie w zakresie polityki prenatalnej. Zakaz aborcji i determinacja władz rządu PiS w obronie płodów dotkniętych zagrożeniami rozwojowymi kończy się w momencie przyjścia dziecka z niepełnosprawnością na świat. Od tej chwili rodzice, w 70\% samotne matki, skazani są na samotne borykanie się z tragedią niepełnosprawnego dziecka. Do kronik cynizmu politycznego powinna trafić propozycja zorganizowania specjalnych pokoi „dla wypłakania się” matki/rodziny po zgonie dziecka z wadami letalnymi. Los dzieci z niepełnosprawnością został upowszechniony przez słynny strajk okupacyjny matek i dzieci na korytarzach sejmowych. Władze rządu i sejmu przez kilka tygodni manifestowały swoje „empatyczne” nastawienia dla całego „zjawiska”. Pełnomocnik rządu ds. dzieci z niepełnosprawnością nie znalazł ani czasu, ani ochoty na spotkanie - w co wręcz trudno uwierzyć! Ogólnie stosunek wszelkich służb państwa do całego zjawiska dokumentuje oświadczenie jednej z matek: „diagnoza o trwałym upośledzeniu dziecka (dla laika widoczna "na pierwszy rzut oka”) i związanych z tym orzeczeniem skutków prawnych, finansowych i innych - trwała 12 lat!".

I tak można by malować obraz „opieki” państwa i władzy, bez specjalnego zróżnicowania ich barw politycznych, nad ludźmi potrzebującymi wsparcia w bardzo różnym zakresie. Trzeba taką prawdę upowszechniać dla potomności, aby obudzić sumienia Polaków z rozdętym ego, pozbawionych poczucia winy, wierzących, że żyją w państwie powszechnej troski i chrześcijańskiego miłosierdzia dla wszelkich potrzeb ludzi słabych. Trzeba upowszechniać zachowania Polaków, aby uleczyć polską duszę lub przynajmniej skłonić do refleksji. Niech do historii polskiego chrześcijaństwa przejdzie obraz białego Polaka - katolika, który własną piersią zasłania wejście do kościoła w Gdańsku - czarnemu dziecku z katolickiej rodziny Polki i czarnego ojca. Obraz młodego nożownika, który dźga nożem parę równolatków trzymających się za ręce, zdiagnozowanych przez niego jako naznaczonych zarazą LGBT. Cofnięcie całkowite przez rząd dotacji dla Telefonu zaufania dla Dzieci i Mlodzieży - w latach 2016-2019 - często ostatniej deski ratunku dla dzieci w sytuacjach krytycznych. Dzisiaj dotacje są żenująco niskie; pokrywają ok. $5-8 \%$ potrzeb.

W mojej opinii pedagogika społeczna - jako dyscyplina naukowa - nigdy jeszcze w Polsce nie przeżywała tak trudnego okresu jak dziś. W czasach komunistycz- 
nych była oskarżana o chrześcijańską genezę i przez to dyskredytowana ideologicznie. Władze komunistyczne natomiast twierdziły, że same budują najwspanialszy świat dla ludu pracującego miast i wsi i żadna pedagogika społeczna do tego im nie jest potrzebna. Władze PiS-u nie ukrywają, że budują świat dla siebie i swoich wyznawców, a reszta albo biernie wykonuje genialne posunięcia władzy, albo jest gorszym sortem i stanowi tylko mierzwę historii.

Władza polityczna nie potrafi racjonalnie rządzić ani procesami społecznymi, ani przedsięwzięciami gospodarczymi. Jej zachowania publiczne nacechowane są arogancją i żenującą propagandą. Z jednej strony manifestuje religijną gorliwość przy równoczesnych manifestacyjnych zachowaniach pogańskich. Manifestacyjnie lekceważy prawa pracownicze i gwarancje socjalne „świata pracy”. Inspiruje i dopuszcza do zachowań policji, która upodla manifestujące kobiety, młodzież i wszelkich manifestujących przeciwników władzy. Korupcja, protekcjonizm, nepotyzm są codziennością. Wbrew interesom i deklaracjom rządzący manifestują pogardę dla środowiska przyrodniczego. Wszelkie reformy są podejmowane z pozycji przekonania o ich słuszności bez śladu wysłuchania opinii publicznej, zdania ekspertów. Takim drastycznym przypadkiem głupoty rządu były reformy oświatowe. Ale najgorsze w tej dziedzinie dopiero nadchodzi!

Zderzenie świata wartości pedagogiki społecznej ze światem wartości władzy politycznej, a szczególnie wynikającej z tych wartości pragmatyki działania władzy pokazuje, że są to dwa obce, niekompatybilne światy.

Czy w tym klimacie, pragmatyce społecznej, systemie moralnym praktykowanym przez rządzącą partię jest miejsce dla humanistycznej dyscypliny naukowej, jaką jest pedagogika społeczna? Owszem, jest nie tylko potrzeba, ale nawet konieczność obrony i budowania nowego/starego ładu moralnego i pragmatyki działania, która uleczy nasz kraj i społeczeństwo po rządach irracjonalnej hybrydy irracjonalizmu z nieodpowiedzialnością!

\section{Bibliografia}

Eco U., Ur-faszyzm, „New York Review of Books” 1995.

Johnson P., Bohaterowie, Warszawa 2009.

„Oblicza PRL”, dodatek historyczny IPN do „Rzeczpospolitej” 2007, 20 listopada, nr 2.

Piketty Th. i in., O demokratyczna Europę, manifest ekonomistów, politologów i publicystów z 20 grudnia 2018 r., podpisany m.in. przez K. Borońską-Hryniewiecką, przekł. A. Krynicka.

Powszechna deklaracja praw człowieka ONZ, 1948.

Radlińska H., Z zagadnień pedagogiki społecznej, „Muzeum” 1908, t. II, Kraków, czasopismo Towarzystwa Nauczycieli Szkół Wyższych.

Raport Międzynarodowej Organizacji Pracy, 2006.

Snyder T., O tyranii. Dwadzieścia lekcji z dwudziestego wieku, Kraków 2017. 